\title{
Soil erosion hazard and mitigation in the Euro-Mediterranean region: do we need more research?
}

\author{
JEAN POESEN ${ }^{1}$
}

\begin{abstract}
Soil erosion represents a geomorphological and geological hazard that may cause property damage, loss of livelihoods and services, social and economic disruption, or environmental damage. Erosion of our soils not only lowers the quality of soils on site, resulting in a drastic reduction of their ecosystem functions that play a vital role in daily life, but causes also significant sediment-related problems off site. To curb soil erosion problems, a range of soil conservation techniques and strategies are applied. So far, ca. 7,000 papers on soil erosion and ca. 15,000 papers on soil conservation in the Euro-Mediterranean region have been published (Web of Science, 2015). One might therefore conclude that we now know almost everything about the various soil erosion processes, their factors and consequences as well as their control so that little new knowledge can still be added to the vast amount of available information. We refute this conclusion by pointing to some major research gaps that need to be addressed if we want to use our soils in the Anthropocene in a more sustainable way and improve environmental conditions worldwide. More specifically the following research needs are addressed: 1) improved understanding of soil erosion processes and their interactions, 2) scaling up soil erosion processes and rates in space and time, 3 ) innovative techniques and strategies to prevent or reduce erosion rates.
\end{abstract}

Keywords: soil erosion processes, anthropogenic soil erosion, upscaling, soil conservation

\section{Introduction}

The total number of research articles on soil erosion in the Euro-Mediterranean region amounts to ca. 7,000 papers whereas ca. 15,000 papers on soil conservation in this region have been produced (Web of Science, 2015). An overview of soil erosion processes, their controlling factors, consequences, prevention and control in Europe was produced by Boardman, J. and Poesen, J. in 2006. Consequently, one may ask the question: do we still need more soil erosion research that produces even more papers? The answer is clearly "yes" and in the following sections some arguments will be provided, after defining some important terms and concepts.

Soil erosion is a geomorphic process that detaches and removes soil material (mineral particles and associated organic matter) from its primary location by natural erosive agents or through human or animal activity. Natural erosive agents include water (ice), wind, and gravity. Human activity refers to soil tillage, land leveling, crop harvesting, road and building construction whereas animal activity comprise trampling and soil removal by burrowing animals.

Soils are a natural resource that play a vital role in daily life given that they perform several important functions, i.e. general capabilities that are crucial for various agricultural, environmental, nature protection, landscape architecture and urban applications. Scientists group these in six key soil functions (BLuM, W.E.H. 1993):

1) Food, fiber and other biomass production;

\footnotetext{
${ }^{1}$ Division of Geography and Tourism, Department of Earth and Environmental Sciences, KU Leuven, Heverlee, Belgium. E-mail: jean.poesen@ees.kuleuven.be
} 
2) Environmental interaction such as water filtering, carbon storage and transformation of substances;

3) Biological habitat and gene pool;

4) Source of raw materials;

5) Physical and cultural heritage and

6) Platform for human-made structures such as buildings and roads.

Soil quality reflects how well a soil performs these functions (То́тн, G. et al. 2007). The $68^{\text {th }}$ United Nations General Assembly has declared 2015 the International Year of Soils in order 1) to raise awareness of and improve teaching on the importance of soils for food security and essential ecosystem functions and 2) to stimulate sustainable soil management (soil conservation) (http://www. fao.org/soils-2015/about/en/).

In many parts of the world, soil erosion lowers soil quality, resulting in for instance environmental degradation and poverty. Soil erosion thus represents a geomorphological and geological hazard that may cause property damage, loss of livelihoods and services, social and economic disruption, or environmental damage (UNISDR 2009).

Erosion not only affects the quality of soils on site, resulting in a drastic reduction of their ecosystem functions that play a vital role in daily life, but causes also significant sediment-related problems off site (e.g. surface water pollution, flooding, river morphology changes, reservoir siltation and coastal development). This explains the relatively large number of soil erosion studies conducted so far.

However, given the large body of literature on this subject, one might conclude that we now know almost everything about the various soil erosion processes, their factors, consequences and their control so that little new knowledge can still be added to the vast body of information that has been collected so far.

I will refute this conclusion by pointing to some major research gaps that need to be addressed if we want to use our soils in a sustainable way and improve environmental conditions worldwide.

\section{Need for improved understanding of soil erosion processes and their interactions}

\section{Water erosion}

Assessing the impacts of climatic and land use changes on rates of soil erosion by water has been and is still the objective of many research projects. During the last $50 \mathrm{yrs}$, most research dealing with soil erosion by water has mainly focused on sheet (interrill) and rill erosion processes operating at the (runoff) plot scale. This is seen in

(1) the numerous field experiments where runoff plots have been installed in order to assess soil loss rates due to sheet and rill erosion under various climatic conditions or land use practices (e.g. for the EuroMediterranean zone (see Maetens, W. et al. 2012a) and

(2) the use of both empirical and processbased field-scale and catchment-scale soil erosion models, addressing mainly sheet and rill erosion, for assessing soil erosion induced by environmental change or for establishing soil erosion risk maps at various scales (Poesen, J. et al. 2003).

However, in many landscapes under different climatic conditions and with different land use types, one can observe the presence and dynamics of various gully types, i.e. ephemeral gullies, permanent or classical gullies and bank gullies (e.g. for Hungary, see Kertész, Á. and JакAв, G. 2011). Field-based evidence suggests that sheet and rill erosion as measured on runoff plots are therefore not always realistic indicators of total catchment erosion nor do they indicate satisfactorily the redistribution of eroded soil within a field. It is through (ephemeral) gully erosion that a large fraction of soil eroded within a field or catchment is redistributed and delivered to water courses.

Over the last decade, significant progress has been made in the understanding of the mechanisms and factors controlling gully erosion in a range of environmental conditions. However, we are still far from being capable to predict soil loss rates by gully ero- 
sion. We also know very little about conditions and factors governing gully infilling. Yet we know that many gullies worldwide have undergone cut and fill cycles. In general, we understand quite well the conditions that lead to gully channel incision, but what caused gully infilling by natural processes?

Subsurface erosion leading to the development of pipes, tunnels (piping, tunneling) and possibly to (discontinuous) gully channels has been observed in a wide range of environments where it may cause very significant soil loss rates (VERACHTERT, E. et al. 2011). Yet we still do not fully understand all mechanisms involved nor are we capable to predict soil losses by subsurface erosion rates (Verachtert, E. et al. 2013).

\section{Anthropogenic soil erosion}

Most research efforts dealing with soil loss caused by environmental change have hitherto mainly focused on natural erosion processes, i.e. water and wind erosion, mass movements (landsliding). Much less attention has been given to anthropogenic soil erosion processes that during the last century have become more important and even dominant in a number of environments. Tillage erosion, caused by soil translocation during tillage operations, is a soil degradation process that cannot be neglected in most cropland areas located on rolling or steep topography in all continents when assessing overall soil erosion rates (e.g. Govers, G. et al. 1994; Poesen, J. et al. 1997). Likewise, leveling of badlands (e.g. in the Mediterranean; Photo 1.) to prepare cropland or grassland induces very high erosion rates (Poesen, J.W.A. and Нооке, J.M. 1997).

Harvesting certain crop types, particularly root and tuber crops, may also induce significant soil losses leading to soil quality losses and significant off site effects (Poesen, J. et al. 2001; Ruysschaert, G. et al. 2007). By far the largest erosion rates occur during soil excavations for constructing for example buildings and roads or during military activities (e.g.
Certini, G. et al. 2013). Particularly "bombturbation" (Hupy, J. and Schaetzl, R. 2006) and digging of trenches in soils of conflict zones causes significant erosion rates, far more important than for instance splash erosion rates. A recent study calculated the following mean soil loss rates (during 4 years) in the vicinity of the World War 1 frontline in West Belgium: i.e. 615 ton/ha due to bomb craters in a 1,262 $\mathrm{km}^{2}$ affected area, 279 ton/ha due to trench digging in a $697 \mathrm{~km}^{2}$ area and 114 ton/ha due to mine craters in a $109 \mathrm{~km}^{2}$ area (Hermans, L. 2015). Integrating these soil losses over a total area of $1,262 \mathrm{~km}^{2}$ that was severely affected by the war resulted in a mean soil loss of 780 ton/ha/4years. Very few studies have attempted to quantify soil loss rates by such processes. It has become obvious that soil erosion in the Anthropocene mainly occurs as a consequence of not only natural erosion processes but by a combination of natural and human-induced soil erosion processes and in an increasing number of case studies mainly due to anthropogenic soil erosion processes. The latter are rarely considered in environmental impact studies.

Most studies investigating soil erosion-related topics in a particular study area, dealt with only one particular erosion process. However, in the real world often several processes causing soil loss are at play and usually they interact with each other resulting in a reinforcement or compensation in terms of soil loss. For instance, concentrated flow erosion and tillage erosion (and deposition) are two processes that often operate simultaneously on cropland and that reinforce each other (Poesen, J. et al. 2011). Other examples are land leveling interacting with gullying and shallow landsliding (BORSELLI, L. et al. 2006), landsliding interacting with piping erosion (VERACHTERT, E. et al. 2013), or the interaction between gullying, landsliding and sediment export by rivers (DE Vente, J. et al. 2006; VANMAERCKE, M. et al. 2012) . In order to make more realistic assessments of soil loss rates and sediment yield at catchment scale, more research attention should go to these interacting erosion processes. 


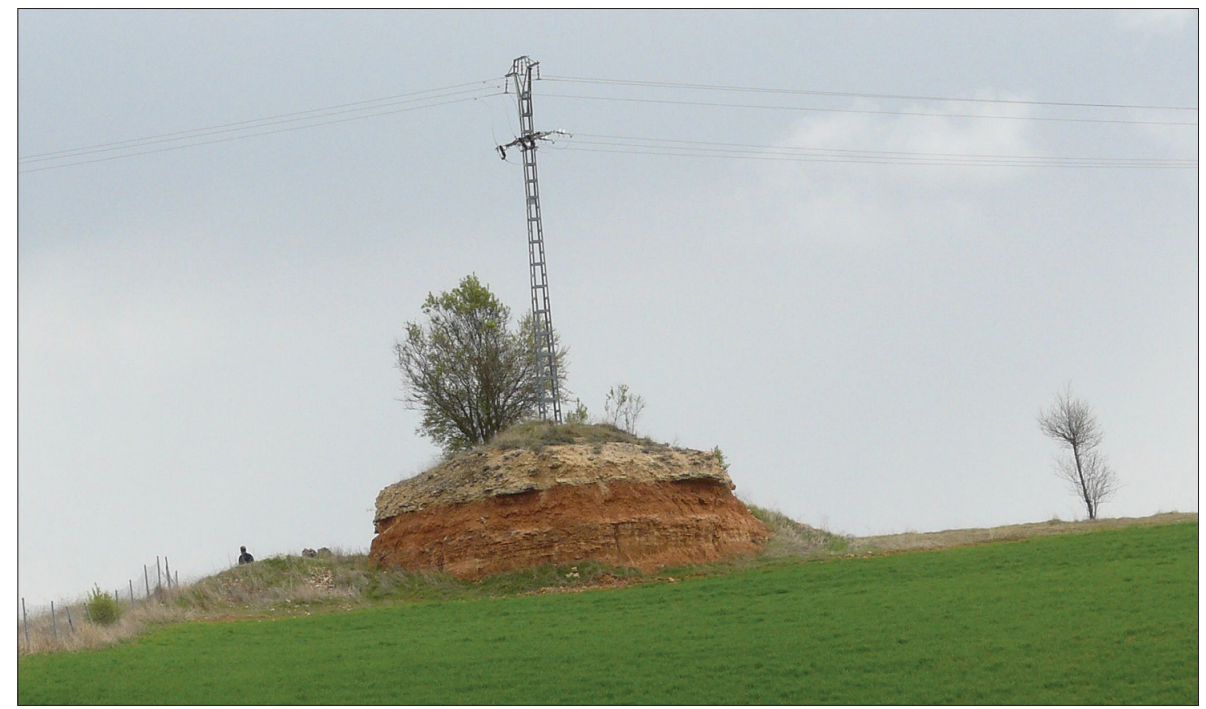

Photo 1. Land leveling of former badlands to create cropland has induced very large soil losses and soil profile truncation (Central Spain, April 2012)

Apart from these interactions, more research is also needed about how erosion processes interact with other earth surface processes. For instance, how does gully erosion affect hydrological processes such as groundwater seepage (exfiltration) or recharge (Poesen, J. et al. 2003)? How does soil erosion affect geochemical processes such as organic carbon storage and depletion (VAN Hemelryck, H. et al. 2011)? To what extent is catchment sediment yield controlled by seismic activity (VANMAERCKE, M. et al. 2014b)? There is a clear need for an improved understanding of interactions amongst different erosion processes as well as between these processes and other earth surface processes.

Scaling up soil erosion processes and rates in space and time: need for improved models and data mining

Many field studies of soil erosion are limited by the size of the study area and the period over which the observations have been made. As to water-related erosion processes the emphasis has been on the runoff plot scale (0.001-0.01 ha; Maetens, W. et al. 2012a) or relatively large catchments (10-100,000 ha; VANMAercKe, M. et al. 2011). Relatively few studies have investigated entire hillslopes or relatively small catchments (0.01-10 ha). To scale up field measurements to larger areas and to longer periods, several procedures are followed, typically involving the use of erosion models. A whole range of models are available: from data-based to physics- or process-based, from simple to complex ones that need many input data (De Vente, J. et al. 2013). Building these models has aided to better understand significant factors that control erosion processes and rates. However, all of them have limitations. For instance, most water erosion models only predict soil loss by sheet and rill erosion, not by gully erosion or piping erosion.

Almost all erosion models do not incorporate anthropogenic soil erosion processes such as tillage erosion or soil loss due to crop harvesting, nor do they account for the interactions between these processes. Catchment sediment yield has been shown to both increase 
and decrease with drainage area. The lack of simple relationships demonstrates complex and scale-dependent process domination throughout a catchment and emphasizes our uncertainty and poor conceptual basis for predicting plot to catchment-scale erosion rates and sediment yields. Changing process domination and process complexity occurring with increasing spatial unit is not represented in most models which are typically formulated on empirical observations made on smaller spatial units, despite the recognition of the role of scale in controlling dominant erosion processes (De Vente, J. et al. 2013).

In order to support model calibration and validation, large-scale data collection and analysis (data mining) of published data on soil erosion rates and controlling factors is now increasingly needed, because of the data availability from many case-studies (often published in the grey literature), but also because scientists lose their data at a rapid rate. The availability of research data typically declines rapidly with article age, as shown recently in ecology (VInEs, T. et al. 2014). The same certainly holds for soil erosion and sediment yield data. Hence there is an urgent need to compile and analyze such valuable metadata before they are lost for future generations. First attempts in this research direction have been recently published: e.g. erosion plot data in Europe (MAETEns, W. et al. 2012b); catchment sediment yield data in Europe (VANMAercke, M. et al. 2011); topographic thresholds for gully headcut development (Torri, D. and Poesen, J. 2014).

\section{Innovative techniques and strategies to prevent erosion or reduce erosion rates}

Overall, there has been much more research focus on rates and factors of particular soil erosion processes than on new techniques and strategies to avoid or to control these processes. Moreover, the relative efficiency of these techniques (as compared to conventional land use practices) has been poorly documented. What can be learned from failures and suc- cesses of soil erosion control programs? Critical evaluations of past soil and water conservation programs are crucial as the past is the key to the future. Analysis of large datasets (case-studies) is one way to solve this issue (e.g. Maetens, W. et al. 2012a).

Innovation in erosion control research is rather limited compared to innovation in erosion process research (Poesen, J. et al. 2003). For instance, we still control gully erosion with techniques (e.g. grassed waterways, check dams) that were already in use ca. 80 years ago (Bennett, H. 1939). Application of these techniques is not always feasible. Therefore more efforts should be made to further develop or to improve erosion control techniques.

Control of soil losses in erosion hot spots (e.g. gully heads and channels, river banks, landslide scars, construction sites, rural settlements in third world countries) remains a big challenge. Traditionally, hard engineering structures (e.g. check dams, gabions, retention walls, anchors or retention ponds) have been installed in such spots as they provide an immediate solution for (gully) channel and slope stability and for reducing sediment production. However, these interventions may not necessarily be sustainable in the long run. Alternatively soft engineering structures, making use of live vegetation (i.e. plant species that have optimal aboveand below-ground biomass characteristics; De Baets, S. et al. 2009; Reubens, B. et al. 2009), brush layers or fascines made from live plant cuttings can be used to control erosion rates, but these take longer to fully stabilize soils.

More research is needed to combine hard and soft engineering approaches in a balanced way that helps ecological restoration of erosion hot spots and that provides a broad spectrum of ecosystem services (Stokes, A. et al. 2014). Along these lines, a better understanding of root properties of indigenous plant species and their potential to control soil erosion by incisive processes, such as concentrated flow erosion or shallow landsliding, is much needed (VAnnoppen, W. et al. 2015). 
A major factor in the implementation of soil erosion control and soil conservation techniques is the social-economic situation (e.g. poverty, level of development, status of forest transition, subsidies, ...) in a given target area (e.g. see GARCiA-Ruiz, J.M. et al. 2013 for the Mediterranean). What are the optimal pathways to implement soil conservation measures and to reduce soil erosion rates: a top-down or a bottom-up approach? If the latter is more effective, how can we stimulate such an approach? These questions require a better understanding of human (society) - environment interactions.

\section{Conclusions}

Despite the vast number of research papers on soil erosion and soil conservation in the EuroMediterranean region published so far, there are still several major challenges for soil erosion researchers which have been discussed above. If future research focuses on these research gaps, we will not only better understand processes and their interactions operating at a range of spatial and temporal scales, their rates as well as their on-site and off-site impacts (which is academically spoken rewarding), but we will also be in a better position to select the most appropriate and effective soil erosion control techniques and strategies which are badly needed for a sustainable use of our soils in the Anthropocene.

Acknowledgement: I acknowledge the support of the EUGEO 2015 organizers and of Zoltán Kovács in particular which made my participation in this congress possible. Thanks also go to the many researchers and colleagues for sharing their research experiences with me during stimulating discussions and all sponsors that funded my research projects.

\section{REFERENCES}

Bennett, H. 1939. Soil Conservation. New York, McGraw-Hill, 993 p.

Blum, W.E.H. 1993. Soil Protection Concept of the Council of Europe and Integrated Soil Research.
In Soil and Environment. Vol 1. Eds.: EIJSACKers, H.J.P. and Hamers, T. Dordrecht, Kluwer Academic Publisher, 37-47.

Boardman, J. and Poesen, J. 2006. Soil Erosion in Europe. Chichester, Wiley, 855 p.

Borselli, L., Torri, D., Øygarden, L., De Alba, S., Martinez-Casasnovas, J., Bazzoffi, P. and JaKab, G. 2006. Land Levelling. Chapter 6.2. In Soil Erosion in Europe. Eds.: BoArdman, J. and Poesen, J. Chichester, Wiley, 643-658.

Certini, G., Scalenghe, R. and Woods, W. 2013. The impact of warfare on the soil environment. EarthScience Reviews 127. 1-15.

De Baets, S., Poesen, J., Reubens, B., Muys, B., De Baerdemaeker, J. and Meersmans, J. 2009. Methodological framework to select plant species for controlling rill and gully erosion: application to a Mediterranean ecosystem. Earth Surface Processes and Landforms 34. 1374-1392.

De Vente, J., Poesen, J. Verstraeten, G., Govers, G., Vanmaercke, M., Van Rompaey, A., Arabkhedri, M. and Borx-FAyos, C. 2013. Predicting soil erosion and sediment yield at regional scales: Where do we stand? Earth-Science Reviews 127. 16-29.

De Vente, J., Poesen, J., Bazoffi, P., Van Rompaey, A. and Verstraeten, G. 2006. Predicting catchment sediment yield in Mediterranean environments: the importance of sediment sources and connectivity in Italian drainage basins. Earth Surface Processes and Landforms 31. 1017-1034.

Garcia-Ruiz, J.M., NADAL-Romero, E., Lana-Renault, N. and Begueria, S. 2013. Erosion in Mediterranean landscapes: changes and future challenges. Geomorphology 198. 20-36.

Govers, G., Vandaele, K., Desmet, P., Poesen, J. and Bunte, K. 1994. The role of tillage in soil redistribution on hillslopes. European Journal of Soil Science 45. (4): 469-478.

Hermans, L. 2015. Bodemverliezen veroorzaakt door bomkraters en loopgraven tijdens WO I in WestVlaanderen. Unpublished thesis. Leuven, Division of Geography, Catholic University of Leuven, $51 \mathrm{p}$.

Hupy, J. and Schaetzl, R. 2006. Introducing "bombturbation," a singular type of soil disturbance and mixing. Soil Science 171. (11): 823-836.

Kertész, Á. and JАКАв, G. 2011. Gully erosion in Hungary, review and case study. In $2^{\text {nd }}$ International Geography Symposium - Mediterranean Environment 2010. Eds.: Efe, R. and Ozturk, M. Book Series: Procedia Social and Behavioral Sciences 19. 693-701

Maetens, W., Poesen, J. and Vanmaercke, M. 2012a. How effective are soil conservation techniques in reducing plot runoff and soil loss in Europe and the Mediterranean? Earth-Science Reviews 115. 21-31.

Maetens, W., Vanmaercke, M., Poesen, J., Jankauskas, B., JANKAUSKIEN, G. and Ionita, I. 2012b. Effects of land use on annual runoff and soil loss in Europe 
and the Mediterranean: A meta-analysis of plot data. Progress in Physical Geography 36. 599-653.

Poesen, J., Nachtergaele, J., Verstraeten, G. and VALEnTin, C. 2003. Gully erosion and environmental change: importance and research needs. Catena 50. (2-4): 91-133.

Poesen, J., Torri, D. and Vanwalleghem, T. 2011. Gully Erosion: Procedures to Adopt When modelling Soil Erosion in Landscapes Affected by Gullying. In Handbook of Erosion Modelling. Eds.: Morgan, R.P.C. and Nearing, M.A. Chichester, Blackwell Publishing. Chapter 19: 360-386. + Plates 16, 17, 18 and 19.

Poesen, J., van Wesemael, B., Govers, G., MartinezFernandez, J., Desmet, P., Vandaele, K., Quine, T. and Degraer, G. 1997. Patterns of rock fragment cover generated by tillage erosion. Geomorphology 18. (3-4): 183-197.

Poesen, J., Verstraeten, G., Soenens, R. and Seynaeve, L. 2001. Soil losses due to harvesting of chicory roots and sugar beet: an underrated geomorphic process? Catena 43. (1): 35-47.

Poesen, J.W.A. and Hooke, J.M. 1997. Erosion, flooding and channel management in mediterranean environments of Southern Europe. Progress in Physical Geography 21. (2): 157-199.

Reubens, B., Poesen, J., Nyssen, J., Leduc, Y., Abraha, A.Z., Tewoldeberhan, S., Bauer, H., Kindeya, G., Deckers, J. and MuYs, B. 2009. Establishment and management of woody seedlings in gullies in a semi-arid environment (Tigray, Ethiopia). Plant and Soil 324. 131-156.

Ruysschaert, G., Poesen, J., Verstraeten, G. and Govers, G. 2007. Soil loss due to harvesting of various crop types in contrasting agro-ecological environments. Agriculture, Ecosystems and Environment 120. 153-165.

Stokes, A., Douglas, G., Fourcaud, T., Giadrossich, F., Gillies, C., Hubble, T., Kim, J., Loades, K., MaO, Z., McIvor, I., Mickovski, S., Mitchell, S., Osman, N., Phillips, C., Poesen, J., Polster, D., Preti, F., Raymond, P., Rey, F., Schwarz, M. and Walker, L. 2014. Ecological mitigation of hill slope instability: ten key issues facing researchers and practitioners. Marschner review. Plant and Soil 377. 1-23.

Torri, D. and Poesen, J. 2014. A review of topographic threshold conditions for gully head development in different environments. Earth-Science Reviews 130. 73-85.

Tóth, G., Stolbovoy, V. and Montanarella, L. 2007. Soil Quality and Sustainability Evaluation - An integrated approach to support soil-related policies of the European Union. EUR 22721 EN. Luxembourg, Office for Official Publications of the European Communities, $40 \mathrm{p}$.
UNISDR 2009. Terminology on Disaster Risk Reduction. United Nations Office for Disaster Risk Reduction. http://www.unisdr.org/we/inform/terminology

Van Hemelryck, H., Govers, G. and Van Oost, K. 2011. Evaluating the impact of soil redistribution on the in situ mineralization of soil organic carbon. Earth Surface Processes and Landforms 36. (4): 427-438.

Vanmaercke, M., Kettner, A., Van Den Eeckhaut, M., Poesen, J., Mamaliga, A., Verstraeten, G., Radoane, M., Obreja, F., Upton, P., Syvitski, J. and Govers, G. 2014a. Moderate seismic activity affects contemporary sediment yields. Progress in Physical Geography 38. (2): 145-172.

Vanmaercke, M., Maetens, W., Poesen, J., Jankauskas, B., Jankauskiene, G. Verstraeten, G. and de Vente, J. 2012. A comparison of measured catchment sediment yields with measured and predicted hill slope erosion rates in Europe. Journal of Soils and Sediments 12. (4): 586-602.

Vanmaercke, M., Obreja, F. and Poesen, J. 2014b. Seismic controls on contemporary sediment export in the Siret river catchment, Romania. Geomorphology 216. 247-262.

Vanmaercke, M., Poesen, J., Verstraeten, G., de Vente, J. and Ocakoglu, F. 2011. Sediment yield in Europe: Spatial patterns and scale dependency. Geomorphology 130. 142-161.

Vannoppen, W., Vanmaercke, M., De Baets, S. and Poesen, J. 2015. A review of the mechanical effects of plant roots on concentrated flow erosion rates. Earth-Science Reviews 150. 666-678.

Verachtert, E., Maetens, W., Van Den Eeckhaut, M., Poesen, J. and Deckers, J. 2011. Soil loss due to piping erosion. Earth Surface Processes and Landforms 36. 1715-1725.

Verachtert, E., Van Den Eeckhaut, M., MartínezMurillo, J.F., Nadal-Romero, E., Poesen, J., Devoldere, S., Wijnants, N. and Deckers, S. 2013. Impact of soil characteristics and land use on pipe erosion in a temperate humid climate: Field studies in Belgium. Geomorphology 192. 1-14.

Verachtert, E., Van Den Eeckhaut, M., Poesen, J. and Deckers, J. 2013. Spatial interaction between collapsed pipes and landslides in hilly regions with loess-derived soils. Earth Surface Processes and Landforms 38. 826-835.

Vines, T., Albert, A., Andrew, R., Debarre, F., Bock, D., Franklin, M., Gilbert, K., Moore, J., Renaut, S. and RenNison, D. 2014. The Availability of Research Data Declines Rapidly with Article Age. Current Biology 24. (1): 94-97.

Web of Science, 2015. All Databases, accessed on June, 21, 2015, http://thomsonreuters.com/thomson-reuters-web-of-science/ 


\title{
Changing Ethnic Patterns of the Carpatho-Pannonian Area from the Late $15^{\text {th }}$ until the Early $21^{\text {st }}$ Century
}

\author{
Edited by: KÁroly KOCSIS and PATriK TÁTRAI \\ Hungarian Academy of Sciences, Research Centre for Astronomy and Earth Sciences \\ Budapest, 2015
}

This is the third, revised and enlarged edition of the Changing Ethnic Patterns of the Carpatho-Pannonian Area. The work is georeferenced and comes with a CD-appendix. The collection of maps visually presents the ethnic structure of the ethnically, religiously and culturally unique and diverse Carpathian Basin and its neighbourhood, the Carpatho-Pannonian area. The volume - in Hungarian and English - consists of three structural parts. On the main map, pie charts depict the ethnic structure of the settlements in proportion to the population based on the latest census data. In the supplementary maps, changes in the ethnic structure can be seen at ten points in time (in 1495, 1784, 1880, 1910, 1930, 1941, 1960, 1990, 2001 and 2011). The third part of the work is the accompanying text, which outlines ethnic trends in the past five hundred years in the studied area. This volume presents the Carpatho-Pannonian area as a whole. Thus, the reader can browse the ethnic data of some thirty thousand settlements in various maps.
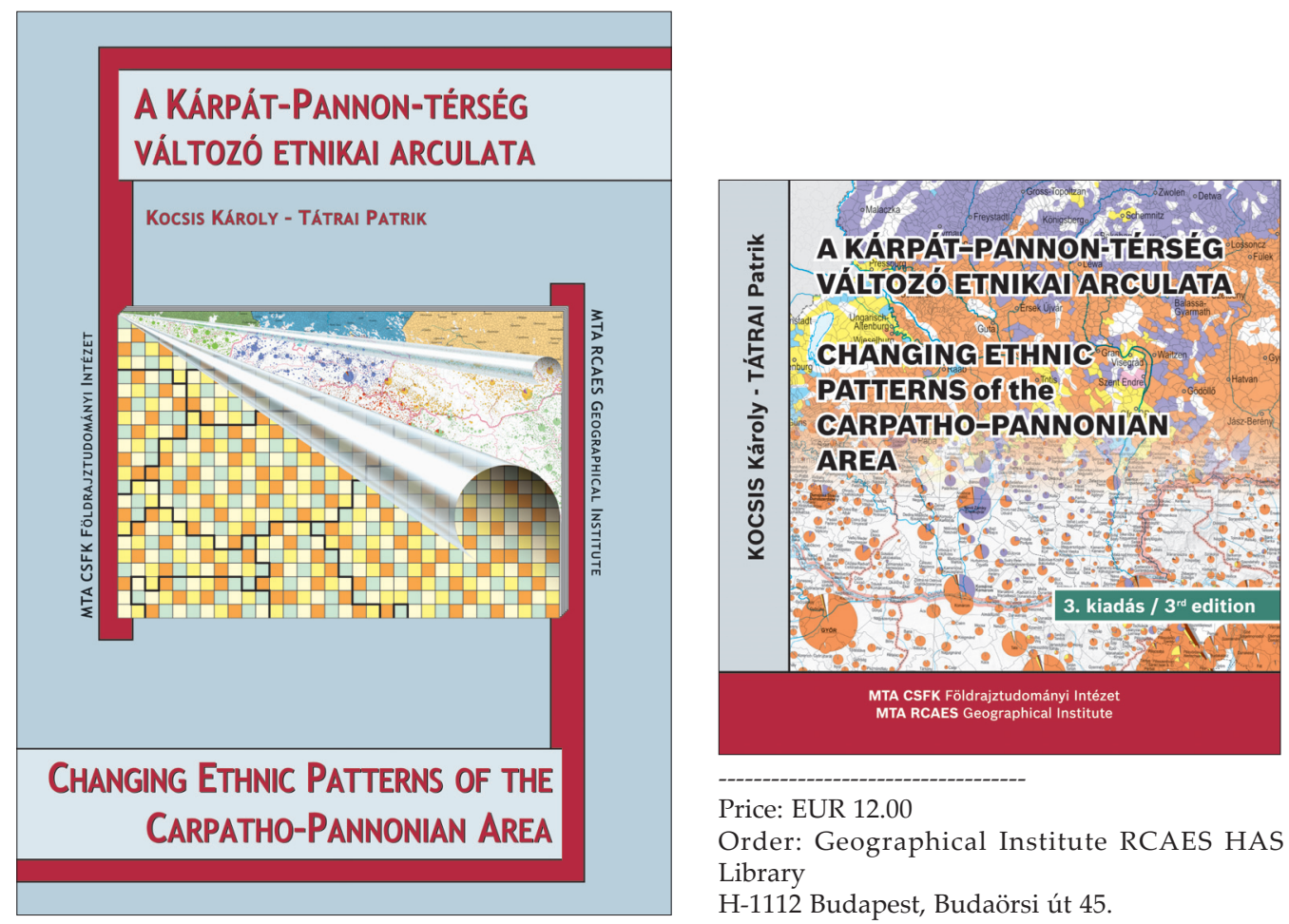

Price: EUR 12.00

Order: Geographical Institute RCAES HAS Library

H-1112 Budapest, Budaörsi út 45 . 